\title{
Motivasyonun İşten Ayrılma Niyeti Üzerine Etkisi: Beş Yıldızlı Oteller Üzerinde Bir Uygulama
}

\author{
DOI: 10.26466/opus.898036 \\ * \\ $\underline{\text { Seray Toksöz }}$ \\ * Dr. Öğr. Üyesi, Esenyurt Üniversitesi, İstanbul/Türkiye \\ E-Posta: sry.gky34@gmail.com \\ ORCID: $\underline{0000-0002-3563-9643}$
}

\section{Öz}

Bu araştırmanın amacı, Türkiye'deki beş yıldızlı otellerde görev yapanların motivasyon düzeylerini belirlemek ve bunun işten ayrilma niyeti üzerindeki olası etkilerini incelemektir. Bu amaca ulaşmak için çalışanlarla anket, insan kaynakları müdürleri ile ise yüz-yüze görüşmeler yapılmıştır. Anket çalışmasında kolayda örnekleme yöntemi kullanılmıştır. Bu anlamda araştırma İstanbul ilinde bulunan 5 yıldizlı otellerde gerçekleştirilmiştir. Bu otellerden 5 tanesi seçilmiş olup araştırma bu otellerin özelinde gerçekleştirilmiştir. 400 anket dağıtılmış olmasına rağmen toplamda 318 anket tam olarak doldurulmuş bir şekilde geri toplanmıştır. Katılımcıların motivasyon seviyelerini belirlemek için anketin ikinci bölümünde Gagne vd. (2010) tarafından geliştirilen "Çok Boyutlu İş Motivasyonu Ölçeği" kullanılmıştır. Katılımcıların işten ayrllma niyetlerini ölçmek üzere Rosin ve Korabik'in (1991) geliştirdiğgi “İşten Ayrılma Niyeti Ölçeği" kullanılmıştır. Otel yöneticilerinin konuya bakış açılarım belirlemek için ise seçilen beş yıldızlı otellerin insan kaynakları departmanı müdürleri ile yarı yapılandırılmış yüz yüze görüşmeler gerçekleştirilmiştir. Yüz-yüze görüşmeler için her otelden bir insan kaynaklarn yöneticisi hedeflenmiştir ve toplamda 5 yüz-yüze görüşme gerçekleştirilmiştir. Araştırma sonuçları göstermiş̧ir ki toplam motivasyonun ve motivasyon alt boyutlarının otel çalışanlarının işten ayrılma niyetleri üzerinde istatistiksel olarak anlamlı ve pozitif yönlü bir etkisi bulunmaktadır.

Anahtar Kelimeler: Motivasyon, çalı̧̧an motivasyonu, işten ayrılma niyeti, 5 yıldızlı oteller 


\title{
Effect of Motivation on Intention to Leave: A Study on Five-Star Hotels
}

\begin{abstract}
The purpose of this research is to determine the level of motivation of those who served in five star hotels in Turkey and to examine the potential impact on the intention to leave it. To achieve this goal, surveys were conducted with employees and face-to-face interviews with human resources managers. The convenience sampling method was used in the survey study. In this sense, the research was carried out in 5 -star hotels in Istanbul. 5 of these hotels were selected and the research was carried out specifically for these hotels. Although 400 questionnaires were distributed, a total of 318 fully completed questionnaires were collected. To determine the motivation levels of the participants, The "Multidimensional Job Motivation Scale" developed by Gagne et al. (2010) was used. To measure the turnover intention of the participants, the intention to quit the scale developed by Rosin and Korabik (1991) was used. Semistructured face-to-face interviews were held with the managers of the human resources department of the selected five-star hotels to determine the point of view of the hotel managers on the subject. A human resources manager from each hotel was targeted for face-to-face interviews, and a total of 5 face-to-face interviews were conducted. The results of the research showed that the total motivation and motivation sub-dimensions have a statistically significant and positive effect on hotel employees' intention to quit.
\end{abstract}

Keywords: Motivation, employee motivation, employee turnover, 5 star hotels 


\section{Giriş}

Motivasyon, insan davranışının merkezinde yer almaktadır. Bartol ve Martin (1998) tarafından motivasyon, insanların davranışlarına yön veren bir güç olarak değerlendirilmektedir. Aynı şekilde Greenberg ve Baron (1997) motivasyonu, bir hedefe ulaşmak için insan davranışını uyandıran, yönlendiren ve sürdüren süreçler dizisi olarak tanımlamaktadırlar. Bu tanım, motivasyonun üç önemli bölümünü ana hatlarıyla belirtmektedir: uyarılma, yönlendirme ve çabanın harekete geçirilmesi. Uyarılma, bir kişinin belirli bir hedefe ulaşmak için sahip olduğu ilk ilgi duygusudur. Yön, insanların nihai sonuca ulaşmak için yapacakları tüm eylemlerdir. Çabanın harekete geçirilmesi ise, hedefe ulaşılana kadar davranışın ısrarı veya sürdürülmesi anlamına gelmektedir. Bu, örneğin terfi isteyen çalışanların terfi sağlanana kadar yukarıda belirtilen bu davranışlarını sürdürmeleri anlamına gelmektedir. Literatürde motivasyonun işten ayrılma niyeti üzerinde etkisinin olduğunu gösteren pek çok araştırma bulunmaktadır. Ancak konunun oteller üzerinde yapılmış araştırmalar noktasında eksik kaldığı gözlemlenmiştir. Gerçekten de işten ayrılma niyeti konaklama işletmeciliği için en sorunlu konulardan biri olmaktadır (Ghiselli, La Lopa ve Bai, 2001) ve motivasyon da, yüksek seviyedeki personel değişiminin en önemli nedenlerinden biri olarak görülmektedir. Bu noktadan hareketle, bu araştırma kapsamında motivasyonun otel çalışanlarının işten ayrılma niyetleri üzerindeki etkisi incelenecektir.

\section{Literatür}

\section{Motivasyon Tanımı}

Literatürde çalışanların motivasyonunu açıklamaya ve analiz etmeye çalışan birçok teori bulunmaktadır. Motivasyon teorileri, içerik (kapsam) ve süreç teorileri olmak üzere iki ana kategoriye ayrılmaktadır (Beardwell, Holden ve Claydon, 2007). İçerik teorileri, motivasyonun ihtiyaçlarına (içeriğine) odaklanmaktadır. Motivasyonun esas olarak ihtiyaçları karşılamak için harekete geçmekle ilgili olduğunu ve davranışları etkileyen temel ihtiyaçları belirlediğini belirtmektedir. Süreç teorileri ise beklentiler, hedefler ve algilara göre motivasyonu ve doyumu etkileyen psikolojik süreçlere odaklanmaktadır. Bir 
başka ifadeyle, davranışı neyin motive ettiğine odaklanan teoriler içerik teorileri, davranışın nasıl motive edildiğine odaklanan teorilere ise süreç teorileri denilmektedir (Küçüközkan, 2015). Bu teoriler birbirilerini tamamlayıcı nitelikte olup, içerik teorileri öncelikle iş tatmini daha sonra harcanan çaba ile bağlantılıdır. Süreç teorileri ise daha çok harcanan çaba ve onun performans sonuçları ile ilgilidir (Koçel, 2015).

\section{Motivasyon Teorileri}

\section{İçerik (Kapsam) Teorileri}

İçerik teorileri, çalışmanın önemine odaklanmaktadır. Bu teoride varsayım, çalışanların iş içinde ve dışında tatmin etmeye çalıştıkları birtakım ihtiyaçlara sahip olduğudur (Beardwell vd., 2007). Bu teori aynı zamanda, tatmin edilmemiş bir ihtiyacın stres ve dengesizlik yaratma durumuna dayanmaktadir. Dengeyi yeniden kurmak için öncelikle ihtiyacı karşılayacak bir hedefin belirlenmesi ve hedefe ulaşılmasına yol açacak bir davranış yolunun seçilmesi gerektiği ileri sürülmektedir. Bu nedenle, tüm davranışların tatmin edilmemiş ihtiyaçlar tarafından motive edildiği ifade edilmektedir. Yazında pek çok içerik teorisine rastlanmaktadır. Örneğin, ihtiyaçlar teorisi, bir sonraki yüksek seviyenin, çalışanları motive etmeden önce, daha düşük seviyedeki ihtiyaçların karşılanması gerektiğini savunan Maslow (1954) tarafından geliştirilmiştir. Daha sonra Herzberg, Mausner ve Snyderman (1967), motivasyonu iki faktöre ayırmışlardır: motive ediciler ve hijyenik etmenler.

\section{Maslow'un İhtiyaçlar Hiyerarşisi}

Maslow (1954) insan ihtiyaçlarını beş seviyede sınıflandırmıştır. Bunlar; fizyolojik ihtiyaçlar, güvenlik ihtiyaçları, sosyal ihtiyaçlar, saygınlık ihtiyaçları ve kendini gerçekleştirme ihtiyaçları. Bu ihtiyaçlar, önem ve ortaya çıkma sırasına göre hiyerarşik bir yapıda düzenlenmiştir. Başka bir deyişle bu teori, daha yüksek seviyedeki insan ihtiyaçlarına geçmeden önce, daha düşük seviyedeki insan ihtiyaçlarının karşılanması gerektiğini öne sürmektedir. Örneğin, birinci sıradaki ihtiyaç karşılanmadan, üçüncü sırayı oluş̧turan ihtiyaçlar ortaya çıkmamaktadır. Herhangi bir ihtiyaç karşılandıkça da, bir sonraki üst düzey ihtiyaç daha güçlü hale gelmektedir (Hall ve Nougaim, 1968). 
Söz konusu ihtiyaç hiyerarşisi aşağıdaki şekildedir (Brigantti, 2004):

1. Fizyolojik İhtiyaçlar: Oksijen, yiyecek, su, barınma vs. gibi insan ihtiyaçlarının en temel ve önemli olanlarını içerdiği için hiyerarşinin en düşük seviyesidir.

2. Güvenlik İhtiyaçları: Bu seviye, tehlikeye karşı korunma, yoksulluğa karşı koruma, adil muamele ve güvenli bir yapılandırılmış ortam sağlama ihtiyaçlarını içermektedir.

3. Sosyal İhtiyaçlar: Bu seviye, bireyin arkadaşlık, sevgi ve bir gruba ait olma duygusuna ihtiyaç duyduğunu ifade etmektedir.

4. Saygınlı İhtiyaçları: Bu seviye, bireyin özsaygısını ve başkaları tarafından saygı görmeyi ifade etmektedir. Bu ihtiyaçlar iki alt grupta sınıflandırılabilmektedir. Birinci grup başarı, yeterlilik, bağımsızlık ve özgürlük arzusu gibi unsurlardan oluşurken; ikinci grup ise diğer insanlardan saygı görme, takdir edilme gibi durumları kapsamaktadır.

5. Kendini Gerçekleştirme İhtiyaçları: Bu, hiyerarşinin en yüksek seviyesidir ve kendini gerçekleştirme arzusudur. Bu seviyedeki ihtiyaçlar, bireyin potansiyellerini gerçekleştirme veya yeteneklerini maksimuma ç1karma arzusunu içermektedir. Kendini gerçekleştiren bireyler ise genel bir iş tatmini geliştirmektedirler.

Teori, çalışanların şirketleri için ellerinden gelenin en iyisini yapabilmeleri adına yeterince rahat bir çevreye ve çalışma koşullarına sahip olmalarını sağlamaya yönelik uygulamaya sahiptir. Bu teori, yöneticilere, ancak bu ihtiyaçlar karşılandığında çalışanların şirketin ve müşterilerin ihtiyaçlarını karşılamaya hazır olduğunu göstermektedir. Bununla birlikte Maslow'un teorisinin çıkarımlarından biri de, en yüksek seviyedeki ihtiyaçlar olan saygı ve kendini gerçekleştirme ihtiyaçlarının motivasyona en büyük itici gücü sağlıyor olmalaridır (Armstrong, 2003).

Maslow'un teorisi, bazı önemli yönetim sonuçlarına sahiptir. Bu sonuçlar, konaklama endüstrisi çalışanlarını yönetim tarzı, iş tasarımı, şirket etkinlikleri, ödül yapısı ve ücret paketleri aracılığıyla motive etmek için fırsatlardır (Tyson ve York, 2002). Örneğin, konaklama işletmeleri çalışanlarının fizyolojik ihtiyaçları, onlara öğle yemeği ve dinlenme molaları vererek sağlanabilecektir. Güvenlik ihtiyaçları, güvenli bir çalışma ortamı ve iş güvenliği sağlanarak; sosyal ihtiyaçlar ise ekip dinamiklerini güçlendirmek suretiyle kabul, aidiyet ve topluluk duygusu yaratarak karşılanabilecektir. Çalışanların başa- 
rılarının farkına vararak, onları önemli projelere atayarak ve takdir edildiklerini hissetmeleri için de onlara statü sağlayarak saygı ihtiyaçları karşılanabilmektedir. Kendini gerçekleştirme ihtiyaçları ise, uzun vadeli hedeflere göre yenilikçiliği, yaratıcılığı ve süreci mümkün kılan zorlu ve anlamlı çalışmalarla giderilebilecektir.

Arnold, Cooper ve Robertson (1998), bu teorinin ödül ve performans yönetimi ile yakın bir ilişkisi olduğunu iddia etmektedir. Yine Arnold vd. (1998) bu teorinin, yönetimlerin, çalışanlarını nelerin motive ettiğini anlamaları açısından oldukça önemli olduğuna vurgu yapmaktadırlar. Benzer şekilde, Huczynski ve Buchanan (2001), iş zenginleştirme, toplam kalite yönetimi, iş süreçlerinin yeniden yapılandırılması, kendi kendini yöneten ekipler gibi pek çok yönetimsel faaliyetlerin Maslow' un ihtiyaçlar teorisi ile ilişkili olduğunu belirtmektedirler.

Ancak bu teori birçok eleştiri ile de karşı karşıya kalmıştır. Örneğin Creech (1995), günümüz toplumunda bu teoride belirlenen temel ihtiyaçların genel olarak karşılandığını ve çalışanların yaratıcı ve zihin genişletici işler gibi daha üst düzey motivasyonlara özlem duyduklarını öne sürmektedir. Frazer-Robinson (1999) ise bu hiyerarşinin genel ilkesine katılsa da, hiyerarşinin ilk üç katmanının yetersiz veya başarısız olması durumunda motivasyon ile bağlantılı olarak paranın çok daha önemli bir konu haline geldiğini savunmaktadır. Arnold vd. (1998) de bu teorinin, insanların ve çevrelerindekilerin kendi ihtiyaç algılarını ve bunların nasıl karşılanabileceğini inşa etme kapasitesini görmezden geldiğini belirtmektedirler.

Genel olarak, yöneticilerin çalışanların yönetimi üzerinde etkili olmaları, onların kendilerini motive etmelerine ve üst düzey performans gösterebilmeleri için kendilerini keşfetmelerine yardımcı olmaları gerekmektedir. Günümüzün hızlı gelişen, son derece rekabetçi konaklama endüstrisi, etkili yöneticinin hem iyi organize olmuş bir yönetici olmasını hem de insanların işyerindeki daha düşük ve daha yüksek seviyedeki ihtiyaçlarını ve davranışlarını anlamada son derece becerikli olmasını talep etmektedir. Bağlılık kazanmak, yetenekleri teşvik etmek, çalışan motivasyonunu ve üretkenliğini sağlamak, yöneticiler ve personel arasında açık iletişim ve güven gerektirmektedir.

\section{Herzberg'in Çift Faktör Teorisi}

Herzberg vd. (1967) çalışma hayatının iki ihtiyaçtan etkilendiğini öne sürmektedirler. Bunlar; motive ediciler ve hijyenik ihtiyaçlardır. Motive ediciler, 
işin kendisinin unsurları ile ilişkilidir. Bu faktörler, çalışan içinde mutlu duygulara veya iyi bir tutuma neden olmaktadır. Tanınma, sorumluluk, kişisel gelişim, başarı ve işin doğası gibi "motive ediciler" veya "tatmin ediciler" motivasyon ihtiyaçlarını karşılamaktadır.

Hijyenik ihtiyaçlar ise doğrudan işin kendisiyle ilgili değil, işin yapılmasını çevreleyen koşullarla ilişkilidir. Hijyenik ihtiyaçlar, denetim, kişiler arası ilişkiler, çalışma koşulları, maaş, şirket politikaları ve idari uygulamalar, yan haklar ve iş güvenliği gibi ortamdaki faktörlerle karşılanmaktadır (Herzberg vd., 1967).

Herzberg vd. (1967), her iki tür ihtiyacın da çalışanları tatmin ettiğini, ancak genel olarak hijyenik ihtiyaçlar çalışanın kabul edilebilir olarak gördüğü seviyenin altına inerse çalışanlarda iş tatminsizliğine neden olacağını belirtmişlerdir. Motive ediciler, bireyin kendini gerçekleştirme ihtiyacını karşıladığı için olumlu iş tutumlarına yol açmaktadırlar.

Herzberg vd. (1967), tatminsizlik yaratan faktörler esas olarak dışsal faktörlerdir ve tatmin edici faktörler de içsel motivasyona dayanmaktadır önermesinde de bulunmaktadır. Hijyenik faktörler dış faktörler olduğundan, bu faktörler çalışma ortamından, maaştan, sosyal haklardan ve şirket politikalarından etkilenmektedirler. Tatminsizlik yaratan faktörler ise denetim, eğitim, performans değerlendirme ve kariyer gelişimini içermektedir (Martinez, 2001).

Herzberg vd. (1967), motive edicilerin, çalışanların nihai hedefi olan kendini gerçekleştirme ihtiyacını karşıladıkları için olumlu iş tutumuna neden oldukların belirtmektedir. Bu motive edicilerin varlığı, büyük bir iş tatmini yaratma potansiyeline sahiptir; ancak motive edenlerin yokluğunda memnuniyetsizlik oluşmamaktadır. Ancak hijyenik faktörler, büyük bir memnuniyetsizliğe neden olma potansiyeline sahiptirler.

Herzberg (1968), çalışanların motivasyonunu çeşitli seviyelerde belirleyen faktörleri özetlemiş̧ir. Bireysel düzeyde yer alan faktörler; iş beklentileri, belirli bir işi yapabilme öz saygısı ve örgütün amaçlarına kıyasla bireyin kendi hedefleri şeklinde sıralanmıştır. Örgütsel düzeyde ise, personel ve müşteriler arasındaki ilişkiler, amirlerin desteği, hizmetlerin tanınması ve takdir edilmesi, iş güvenliği, maaş vb. faktörler sıralanmıştır.

Sonuç olarak, Maslow ve Herzberg teorileri, bireyin genel tatmin ihtiyacını karşılayan ve olumlu iş tutumlarına yol açan faktörler olduğu konu- 
sunda hemfikirdir. Maslow'un ihtiyaçlar hiyerarşisi, Herzberg teorisi üzerinde belirli bir etkiye sahip olmasa da, diş faktörlerin motivasyon üzerinde sınırlı bir etkiye sahip olduğu fikrini güçlendirmektedir. Örneğin, hayatta kalmakla ilgilenmeyen bir kişiye daha fazla yiyecek, sıcak giysiler veya barınak vermenin, kendini gerçekleştirme fırsatı sunmanın yanında çok daha az değeri olacaktır (Vroom, 1964; Csikzentmihalyi, 2003).

Motivasyonla ilgili teoriler, çoğunlukla yönetime odaklanan çalışmalara dayanmaktadır. Literatürde, oldukça fazla sayıda çalışanların iş tatmini düzeyine ilişkin motivasyon çalışmaları yapılmıştır. Ancak, literatürde özellikle konaklama sektörü çalışanları için önemli olan motivasyon faktörleri hakkında oldukça az bilgi bulunmaktadır. Konaklama sektöründe görev yapan çalışanların işlerini algılama biçimleri ve motivasyonları üzerindeki çeşitli etkilere verdikleri önem konusunda daha iyi bir kavrayış elde etmek, bu çalışanların performansını artırmak için stratejiler geliştirmeye yardımcı olacaktir.

\section{Süreç Teorileri}

Süreç teorisyenleri, insanların beklentilerini netleştirmenin ve bunu çalıştıkları işyerleri ile ilişkilendirmenin, iş performansını ve işgücü verimliliğini artıracağını savunmaktadırlar. Bu yaklaşımı benimseyen pek çok teori yazında bulunmaktadır.

\section{Vroom'un Beklenti Teorisi}

Vroom (1964) tarafından geliştirilen beklenti teorisine göre, elde edilen iş ve görev başarısı büyük ölçüde ödüllendirilmiş bir davranışın fonksiyonu olmaktadır. Teori, insanların, eylemlerinin arzu ettikleri neticeler ile sonuçlanacağına inandıklarında, çabalarını belirli bir yönde genişleteceklerini savunmaktadır (Argyris, 1999). Vroom (1964), çalışanların bilinçli olarak bir davranışı diğerine tercih etme seçimini yaptıklarını; çünkü tercih ettikleri davranışı gerçekleştirmenin daha değerli bir sonuca (örneğin bir terfi) ulaşacağına inandıklarını öne sürmektedir. 


\section{Adam'ın Eşitlik Teorisi}

Adams (1963) tarafından geliştirilen "eşitlik teorisi" ise, başkalanı tarafından görülen muameleye kıyasla insanların kendilerine ne kadar adil davranıld1ğına dair hislerine odaklanmaktadır.

\section{Hedef Teorisi}

Hedef Teorisi ise temeli, insanların amaçlarının veya niyetlerinin davranışları belirlemede önemli bir rol oynadığına dayanmaktadır. Hedefler, çalışma davranışını ve performansı yönlendirmekte ve belirli sonuçlara veya geri bildirimlere yol açmaktadır (Mullins, 2005).

Günümüzde de yukarıda açıklanan kuramların geçerliliğini yitirmediği, tüm bu kuramların aslında çağdaş motivasyon anlayışının şekillenmesine yardımcı olduğu söylenebilmektedir. Örneğin Kotler (1999), değişimin önündeki büyük engellere rağmen insanları doğru yönde hareket etmeleri için motive etmenin ve ilham vermenin, ancak çoğu zaman kullanılmayan insan ihtiyaçlarına, değerlerine ve duygularına başvurarak gerçekleşebileceğini savunmaktadır. Benzer şekilde Kouzes ve Posner (1995) de dış teşviklere ve baskılara güvenmenin insanları ellerinden gelenin en iyisini yapma konusunda özgürleştirmediğini ve liderleri insanların neden mükemmel olmak istediğini anlamaktan alıkoyduğunu öne sürmektedirler.

\section{İşten Ayrılma Niyeti ve Motivasyon İlişkisi}

İşten ayrılma niyeti konaklama işletmeciliği için en sorunlu konulardan biri olmaktadır (Ghiselli vd., 2001). Motivasyon da yüksek seviyedeki personel değişiminin en önemli nedenlerinden biri olarak görülmektedir. Herzberg'in çift faktör teorisi, motivasyon faktörlerini ve hijyen faktörlerini ayırt ederek, konaklama endüstrisindeki çalışanlar için karmaşık motivasyon konusunu açıklığa kavuşturmaya yardımcı olmaktadır. Herzberg' in teorisine göre, motive edici, uzun süreli tutumları ve memnuniyeti teşvik eden iş faktörleridir. Bu motive edicilerin varlığı, büyük bir iş tatmini yaratma potansiyeline sahiptir; ancak motivasyon kaynaklarının yokluğunda memnuniyetsizlik oluşmamaktadır. Öte yandan, büyük bir memnuniyetsizlik yaratma potansiyeline sahip olan hijyen faktörleri ve bunların yokluğu, yüksek düzeyde bir 
memnuniyet yaratmamaktadır. Bu teori kullanılarak, yüksek işten ayrılma niyetine neden olan faktörler araştırılabilmekte ve işgüicü değişiminde motivasyon eksikliğinin rolü belirlenebilmektedir.

\section{Motivasyonun İşten Ayrılma Niyeti Üzerindeki Etkisi}

Fisher ve Locke (1992) gerçekleştirdikleri araştırmada, çalışan motivasyonu ile birtakım değişkenler arasındaki ilişkiyi incelemişlerdir. Araştırma sonuçları, çalışan motivasyonu ile işgücü devri, işe devam durumu ve işe geç kalma değişkenleri arasında istatistiksel açıdan anlamlı ilişki olduğunu göstermektedir. Bu anlamda, işletmeler açısından çalışan motivasyonunun hangi düzeyde olduğunun ve nelerden etkilendiğinin bilinmesi oldukça büyük önem arz etmektedir (Yüksel, 2002).

Yoon ve Suh (2003) tarafından çalışan motivasyonu yüksek seviyede olan çalışanların, çalışmaya isteklerinin de yüksek seviyede olduğu ve böylelikle daha çok çalışarak diğer çalışanlara kıyasla daha yüksek performans sergiledikleri belirtilmektedir. Aynı zamanda yüksek motivasyona sahip çalışanlar çalıştıkları kuruma karşı daha ilgili olmakta ve kendilerini daha kaliteli hizmet verebilmek adına motive etmektedirler. Dolayısıyla çalışan motivasyonu, çalışan performansı, işgücü devir hızı, işletmenin verimliliği, büyüme hızı ve genel başarısı üzerinde oldukça önemli etkisi olduğu belirtilmektedir (Örücü ve Esenkal, 2005).

Benzer olarak Robbins, Odendaal ve Roodt (2003) de çalışan motivasyonu seviyesi yüksek olan çalışanların işlerine karşı daha pozitif yaklaştıklarını, çalışan motivasyonu düşük olan çalışanların ise tam tersi olarak işlerine negatif psikoloji ile yaklaştıklarını belirtmektedirler. Çalışan motivasyonu, çalışanların hem psikolojik hem de fizyolojik sağlıkları üzerinde etkisi olan stres faktörünün azaltılması noktasında önemli bir rol oynamaktadır. İşe devam etme ve işten ayrılma niyeti gibi unsurlar da çalışan motivasyonunun önemini daha da çok arttırmaktadır. Özellikle çalışanların motivasyon seviyeleri ile işten ayrılma niyetleri arasında oldukça yüksek seviyede bir ilişki olduğuna dikkat çekilmektedir (Kök, 2006).

Bunlara ek olarak, düşük seviyedeki çalışan motivasyonu çalışan kişilerde duygusal tükenmeye sebep olabilmektedir. Duygusal tükenmenin, iş stresi ile birlikte işe karşı duyarsızlaşma, çatışma ve iş ile ilgili gerginlik unsurları sebebiyle işten ayrılma niyeti gibi ilişkilerde kısmi aracı rolü bulunmaktadır 
(Yürür ve Keser, 2011). Aynı zamanda duygusal tükenme, etkileşim adaletiyle örgütsel bağlılık ve işten ayrılma niyeti, kişilik özelliklerinden biri olan dışsal kontrol odağı ile işten ayrılma niyeti ve iş talepleri sebebiyle işten ayrılma niyeti gibi ilişkilerde ise tam aracı değişken rolü oynamaktadır (Hobfoll, 2001).

\section{Yöntem}

Bu araştırmanın amacl, Türkiye'deki beş yıldızlı otellerde görev yapanların motivasyon düzeylerini belirlemek ve bunun işten ayrılma niyeti üzerindeki olası etkilerini incelemektir. Bu araştırmanın amacına ulaşmak için realist yaklaşım benimsenmiş ve araştırma metodolojilerinden betimleyici yaklaşım seçilmiştir. Betimsel bir çalışma yürütmek amacıyla bu çalışmada yapılandırılmış anket uygulanmış ve hem birincil hem de ikincil veriler kullanılmıştır.

Veri toplama açısından araştırma üç aşamadan oluşmaktadır. İlk aşamada ikincil veri araştırması yapılmıştır. İkincil veri araştırmasının amacı, teorik çerçeveyi gözden geçirmek ve bu araştırmanın alt yapısını oluşturmaktır. Bir başka deyişle çalışmada, kavramsal çerçeveyi oluşturmak amaciyla ikincil veriler toplanmıştır. İkincil veri toplamada, çalışan motivasyonu ile ilgili kitap ve makaleler taranmıştır.

Sonraki aşamada ise birincil veriler yarı yapılandırılmış anket yoluyla toplanmıştır. Anketin amacı, Türkiye'deki beş yıldızlı otellerde görev yapan çalışanların motivasyon düzeylerini incelemek ve işten ayrılma niyetlerini incelemek ve varsa aralarındaki ilişkiyi ortaya çıkartmaktır. Bu amaçla hazırlanan anket üç bölümden oluşmuştur. Anketin ilk bölümünde demografik soru formu yer almıştır. Bu formda toplam 6 adet soru sorulmuştur. Bu sorular araştırmaya katılanların cinsiyet, yaş, medeni durum, eğitim seviyesi, çalışma durumu ve çalışma sürelerine ilişkindir.

Katılımcıların motivasyon seviyelerini belirlemek için anketin ikinci bölümünde Gagne vd. (2010) tarafından geliştirilen “Çok Boyutlu İş Motivasyonu Ölçeği” kullanılmıştır. Anketin bu kısmında 18 soru sorulmuş olup 7'li Likert sisteminde cevaplar alınmıştır. Ölçek toplamda 6 alt boyuttan oluşmaktadır: "motive olmama, dışsal düzenleme-sosyal, dişsal düzenleme-maddesel, içe yansitılan düzenleme, kişisel düzenleme ve içsel motivasyon". 
Anketin son bölümünde ise katılımcıların işten ayrılma niyetlerini ölçmek üzere Rosin ve Korabik'in (1991) geliştirdiği İșten Ayrılma Niyeti Ölçeği kullanılmıştır. Bu ölçek toplam 4 sorudan oluşmakta olup 5li likert skalasında cevaplanmaktadir.

Araştırmanın üçüncü ve son aşamada ise, seçilen beş yıldızlı otellerin insan kaynakları departmanı müdürleri ile yarı yapılandırılmış yüz yüze görüşmeler gerçekleştirilmiştir. Yarı yapılandırılmış yüz yüze görüşmelerin amacı, çalışanların motivasyonuna ilişkin yönetim bakış açılarını belirlemektir.

Bu çalışmanın evreni, Türkiye'deki var olan beş yıldızlı otellerin çalışanlarıdır. Bu çalışma için kolayda örnekleme yöntemi kullanılmıştır. Bu örneklem yönteminde, popülasyondan birimlerin seçimi kolay bulunabilirliğe ve/veya erişilebilirliğe dayanmaktadır. Bu anlamda araştırma İstanbul ilinde bulunan 5 yıldızlı otellerde gerçekleştirilmiştir. Bu otellerden 5 tanesi seçilmiş olup araştırma bu otellerin özelinde gerçekleştirilmiştir. Bu otellerde toplam çalışan sayısı 780 olarak tespit edilmiştir. Bu evren sayısı özelinde yüzde 99 güvenirlik ve yüzde 5 hata payı ile örneklem hesaplaması yapıldığında çıkan sonuç 359 olmuştur. Bu anlamda toplam 400 anket seçilen otellerin çalışanlarına eşit olarak dağıtılmıştır. 1 ay toplama süresi belirlenmiştir ve bu süre sonunda geri toplanan anketler analize dahil edilmiştir. 400 anket dağıtılmış olmasına rağmen toplamda 318 anket tam olarak doldurulmuş bir şekilde geri toplanmıştır. Bu anlamda bu araştırmada toplam 318 anket analize dahil edilmiştir. Yüz-yüze görüşmeler için ise seçilen her otelden bir insan kaynakları yöneticisi hedeflenmiştir ve toplamda 5 yüz-yüze görüşme gerçekleştirilmiştir.

Anket sonuçları SPSS kullanılarak analiz edilmiştir. Buna göre önce betimsel analizler yapılmış ardından da ilişki analizleri yapılarak motivasyon ve işten ayrılma niyeti arasında var olabilecek ilişkiler tespit edilmiştir. Yüzyüze görüşmeler ise hikaye anlatımı tekniği kullanılarak analiz edilmiştir. 


\section{Bulgular}

\section{Çalışan Bakış Açısı}

Tablo 1. Katılımcılarn demografik özellikleri

\begin{tabular}{|c|c|c|}
\hline Demografik özellikler & & Yüzde (\%) \\
\hline \multirow[t]{2}{*}{ Cinsiyet } & Erkek & 62 \\
\hline & Kadın & 38 \\
\hline \multirow[t]{4}{*}{ Yaş } & 21'den küçük & 15 \\
\hline & $21-30$ & 62 \\
\hline & $31-40$ & 15 \\
\hline & $41-50$ & 8 \\
\hline \multirow[t]{3}{*}{ Medeni durum } & Bekar & 43 \\
\hline & Evli & 42 \\
\hline & Boşanmış & 15 \\
\hline \multirow[t]{5}{*}{ Eğitim seviyesi } & İlkokul & 4 \\
\hline & Ortaokul & 34 \\
\hline & Lise & 34 \\
\hline & Üniversite & 20 \\
\hline & Yüksek lisans & 8 \\
\hline \multirow[t]{2}{*}{ Çalışma durumu } & Tam zamanl & 38 \\
\hline & Yarı zamanlı & 62 \\
\hline \multirow[t]{3}{*}{ Çalışma süresi } & 1 y1ldan az & 19 \\
\hline & $1-3 \mathrm{yll}$ & 66 \\
\hline & 4 yildan fazla & 15 \\
\hline
\end{tabular}

Yukarıda yer alan tablo, araştırmaya dahil olan katılımcıların demografik özelliklerine ilişkin bilgileri göstermektedir. Sonuçlara göre, katılımcların çoğunluğunu erkekler (\%62) oluşturmaktadır. Katılımcıların yine çoğunluğu (\%62) 21-30 yaş aralığındadır. Katılımcıların \%43'ü evli ve \%42'si bekar bireylerden oluşmaktadır. Eğitim seviyelerine bakıldığında ise, katılımcıların \%34'ünün lise mezunu, \%34'ünün ortaokul mezunu ve \%20'sinin de üniversite mezunu oldukları anlaşılmaktadır. Katılımcıların çoğunluğu (\%62) işyerlerinde yarı zamanlı çalışmakta olup, yine çoğunluğu da (\%66) 1-3 yıldır aynı işyerinde çalışmaktadırlar.

Tablo 2. Motivasyon ölçeği ve alt faktörlerinin betimsel istatistikleri

\begin{tabular}{|c|c|c|c|c|c|}
\hline & $\mathbf{N}$ & Minimum & Maximum & Ortalama & Std. Sapma \\
\hline Motive olmama & 318 & 1,00 & 5,00 & 2,2872 & 82502 \\
\hline İçsel motivasyon & 318 & 1,00 & 7,00 & 3,9958 & 1,01201 \\
\hline Dişsal düzenleme-sosyal & 318 & 1,00 & 5,00 & 3,9287 & 83001 \\
\hline Kişisel düzenleme & 318 & 1,00 & 6,00 & 4,1426 & 63319 \\
\hline Dışsal düzenleme-maddesel & 318 & 1,00 & 6,67 & 3,7128 & 96302 \\
\hline Içe yansıtılan düzenleme & 318 & 1,00 & 6,33 & 3,6069 & 1,09083 \\
\hline Motivasyon - Toplam & 318 & 2,00 & 5,11 & 3,6123 & 41220 \\
\hline
\end{tabular}


Yukarıda yer alan tabloya göre, "kişisel düzenleme" alt boyutu en yüksek değere sahip alt boyuttur (Min: 1,00; Max: 6,00; Ortalama: 4,1426). Motivasyon ölçeği alt boyutlarından en düşük ortalamaya sahip alt boyut ise "motive olmama" alt boyutu olmuştur (Min: 1,00; Max: 5,00; Ortalama: 2,2872). Çal1şanların toplam motivasyon ölçeğinden aldıkları puan ortalaması ise 3,6123 olarak belirlenmiştir.

Tablo 3. İşten ayrulma niyeti betimsel istatistikleri

\begin{tabular}{llllll}
\hline & $\mathbf{N}$ & Minimum & Maximum & Ortalama & Std. Sapma \\
\hline İşten ayrılma niyeti & 318 & 1,00 & 5,00 & 3,4356 &, 73022 \\
\hline
\end{tabular}

Yukarıda yer alan tabloya göre, çalışanların işten ayrılma niyetine ilişkin ortalama puanı 3,4356'dır (Min: 1,00; Max: 5,00).

Tablo 4. Korelasyon analizi

\begin{tabular}{|c|c|c|c|c|c|c|c|c|}
\hline & & $\begin{array}{l}\text { Motive } \\
\text { olamama }\end{array}$ & $\begin{array}{l}\text { İçsel } \\
\text { motivasyon }\end{array}$ & $\begin{array}{l}\text { Dişsal } \\
\text { düzenleme - } \\
\text { sosyal }\end{array}$ & $\begin{array}{l}\text {-Kişisel } \\
\text { düzenleme }\end{array}$ & $\begin{array}{l}\text { Dişsal } \\
\text { düzenleme } \\
\text { maddesel }\end{array}$ & $\begin{array}{l}\text { İçe } \\
\text {-yansitılan } \\
\text { düzenleme }\end{array}$ & $\begin{array}{l}\text { Motivasyon } \\
\text { - Toplam }\end{array}$ \\
\hline $\begin{array}{l}\text { İşten } \\
\text { ayrılma }\end{array}$ & $\begin{array}{l}\text { Pearson } \\
\text { (r) }\end{array}$ &, $918^{* *}$ & ,649** & ,587 & 690 & 716 & ,755 & ,786 \\
\hline niyeti & Sig. $(p)$ & ,000 & ,002 & ,000 & ,000 & ,001 & ,000 & ,000 \\
\hline
\end{tabular}

Yukarıda yer alan tabloya göre, çalışanların işten ayrılma niyeti ile motivasyon toplam puanı arasında istatistiksel olarak anlamlı ve pozitif ilişki bulunmaktadır ( $\mathrm{r}=0.796 ; \mathrm{p}=0.00<0.05)$. Aynı zamanda, işten ayrılma niyeti ile "motive olmama" alt boyutu ( $\mathrm{r}=0.918 ; \mathrm{p}=0.00<0.05)$, "içsel motivasyon" alt boyutu ( $\mathrm{r}=0.649 ; \mathrm{p}=0.002<0.05)$, "dişsal düzenleme-sosyal" alt boyutu ( $\mathrm{r}=0.587$; $\mathrm{p}=0.00<0.05)$, "kişisel düzenleme" alt boyutu ( $\mathrm{r}=0.690$; $\mathrm{p}=0.00<0.05)$, "dişsal düzenleme-maddesel" alt boyutu $(\mathrm{r}=0.716$; $\mathrm{p}=0.001<0.05)$ ve "içe yansıtılan düzenleme" alt boyutu $(\mathrm{r}=0.755 ; \mathrm{p}=0.00<0.05)$ arasında da pozitif ve istatistiksel olarak anlamlı ilişki bulunmaktadır.

Tablo 5. Regresyon analizi

\begin{tabular}{|c|c|c|c|c|}
\hline & $\mathbf{R}^{2}$ & $\beta$ & Std. hata. & $p$ \\
\hline *Isşten ayrılma niyeti $\leftarrow$ Motive olamama & .235 & .725 & .014 & .000 \\
\hline İşten ayrılma niyeti $\leftarrow$ İçsel motivasyon & .174 & .412 & .014 & .000 \\
\hline İşten ayrılma niyeti $\leftarrow$ Dişsal düzenleme-sosyal & .171 & .520 & .010 & .030 \\
\hline İşten ayrılma niyeti $\leftarrow$ Kişisel düzenleme & .270 & .530 & .019 & .000 \\
\hline İşten ayrılma niyeti $\leftarrow$ Dişsal düzenleme-maddesel & .373 & .425 & .012 & .002 \\
\hline İşten ayrılma niyeti $\leftarrow$ İçe yansıtılan düzenleme & .273 & .670 & .020 & .008 \\
\hline İşten ayrılma niyeti $\leftarrow$ Motivasyon-Toplam & .325 & .375 & .014 & .000 \\
\hline
\end{tabular}

*Bağımlı değişken: İşten ayrılma niyeti 
İşten ayrılma niyeti ile motivasyon ve alt boyutları arasında yapılan regresyon analizi sonuçlarına göre, toplam motivasyonun işten ayrılma niyeti üzerinde istatistiksel olarak anlamlı ve pozitif yönlü $(\beta=.475 ; \mathrm{p}=0.00<0.05) \mathrm{bir}$ etkisi bulunmaktadır.

Motivasyon ölçeği alt boyutlarından "motive olmama" alt boyutunun $(\beta$ $=.725 ; \mathrm{p}=0.00<0.05)$, "içsel motivasyon" alt boyutunun $(\beta=.412 ; \mathrm{p}=0.00<0.05)$, "dışsal düzenleme-sosyal" alt boyutunun $(\beta=.520 ; \mathrm{p}=0.030<0.05)$, "kişisel düzenleme" alt boyutunun $(\beta=.530 ; \mathrm{p}=0.00<0.05)$, "dişsal düzenleme-maddesel" alt boyutunun $(\beta=.425 ; p=0.002<0.05)$ ve "içe yansitılan düzenleme" alt boyutunun $(\beta=.670 ; p=0.008<0.05)$ da işten ayrılma niyeti üzerinde pozitif yönlü ve istatistiksel olarak anlamlı etkisi bulunmaktadır.

\section{Yönetim Bakış Açısı}

Araştırmaya katılan insan kaynakları müdürlerinin bakış açlarında genel olarak pek çok benzerlik ve farklılık olduğu gözlemlenmektedir. Örneğin benzerlikler açısından, otellerin hemen hepsinde danışman yaklaşımının olduğu ve insan kaynakları müdürlerinin kapısının çalışanlarına her zaman açık olduğu belirlenmiştir. Ayrıca insan kaynakları müdürleri, ekip çalışmasının çalışan motivasyonunda çok önemli bir role sahip olduğuna ve bu nedenle iyileştirilmesi gerektiğine inandıklarını belirtmişlerdir. Ancak görüşmelerden elde edilen bulgular göstermektedir ki yönetim ile çalışanlar arasında sağlıklı bir çift yönlü iletişim bulunmamaktadır. Nitekim, katılan insan kaynakları müdürlerinin hemen hepsi açıklamalarında, yıllık bazda yapılan performans değerlendirmeleri dışında iki yönlü iletişim hakkında hiçbir söylemde bulunmamışlardır. Bu durum çalışanlara kapılarının açık olduğunu söyleyen yöneticiler anlamında da düşündürücüdür. Çünkü, iletişime açık müdürlerin daha fazla iletişimde bulunmaları beklenecektir. Benzer şekilde görüşmelerden elde edilen bir başka durum ise otellerde var olan ödül sistemlerine ilişkin olmuştur. Katılan insan kaynakları müdürlerinin hemen hepsi otellerinde birçok ödül programı olduğu, ancak çalışanların çoğunun var olan bu mevcut ödül programından memnun olmadığı belirtilmişlerdir. Bununla birlikte otel çalışanlarında herhangi bir kafa karışıklığına sebep olmaması açısından bir ceza sistemi de bulunmamaktadır. Aynı şekilde, insan kaynakları müdürleri, çalışanlar ile yönetim arasında \%100 güvenin olması 
gerektiğine inanmakta olsalar da çalışanların yönetime güvenip güvenememe konusunda birtakım kafa karışıklıkları mevcuttur önermesinde bulunmuşlardır. Tüm bu bulgulara rağmen katılan insan kaynakları yöneticilerine göre otel çalışanları arasında var olan motivasyon eksikliği işten ayrılma niyetleri üzerinde etkili bir faktör değildir. Otel çalışanları için en önemli işten ayrılma niyetini etkileyen faktörler: çalışma koşullarının zorluğu, uzun çalışma saatlerinin varlığı ve düşük ücret şeklinde ifade edilmiştir.

\section{Sonuç}

Bu araştırmanın amacı, Türkiye'deki beş yıldızlı otellerde görev yapanların motivasyon düzeylerini belirlemek ve bunun işten ayrilma niyeti üzerindeki olası etkilerini incelemektir. Bu amaca ulaşmak için çalışanlarla anket, insan kaynakları müdürleri ile ise yüz-yüze görüşmeler yapılmıştır. Anket çalışmasında kolayda örnekleme yöntemi kullanılmıştır. Bu anlamda araştırma İstanbul ilinde bulunan 5 yıldızlı otellerde gerçekleştirilmiştir. Bu otellerden 5 tanesi seçilmiş olup araştırma bu otellerin özelinde gerçekleştirilmiştir. 400 anket dağıtılmış olmasına rağmen toplamda 318 anket tam olarak doldurulmuş bir şekilde geri toplanmıştır. Katılımcıların motivasyon seviyelerini belirlemek için anketin ikinci bölümünde Gagne vd. (2010) tarafından geliştirilen "Çok Boyutlu İş Motivasyonu Ölçeği" kullanılmıştır. Katılımcıların işten ayrılma niyetlerini ölçmek üzere Rosin ve Korabik'in (1991) geliştirdiği “İşten Ayrılma Niyeti Ölçeği”" kullanılmıştır. Otel yöneticilerinin konuya bakış aç1larını belirlemek için ise seçilen beş yıldızlı otellerin insan kaynakları departmanı müdürleri ile yarı yapılandırılmış yüz yüze görüşmeler gerçekleştirilmiştir. Yüz-yüze görüşmeler için her otelden bir insan kaynakları yöneticisi hedeflenmiştir ve toplamda 5 yüz-yüze görüşme gerçekleştirilmiştir.

Araştırma sonuçları göstermiştir ki toplam motivasyonun işten ayrılma niyeti üzerinde istatistiksel olarak anlamlı ve pozitif yönlü bir etkisi bulunmaktadır. Motivasyon ölçeği alt boyutlarından "motive olmama" alt boyutunun, "içsel motivasyon" alt boyutunun, "dışsal düzenleme-sosyal" alt boyutunun, "kişisel düzenleme" alt boyutunun, "dışsal düzenleme-maddesel" alt boyutunun ve "içe yansittlan düzenleme" alt boyutunun da işten ayrılma niyeti üzerinde pozitif yönlü ve istatistiksel olarak anlamlı etkisi bulunmaktadır. Bu anlamda otel çalışanları açısından motivasyon tümüyle işten ayrılma 
niyetini etkilemektedir denilebilecektir. Ancak bu araştırma kapsamında gerçekleştirilen yüz-yüze görüşme sonuçlarına göre yöneticiler açısından çal1şanlarda var olabilecek motivasyon eksikliği işten ayrılma niyeti üzerinde etkili bir faktör değildir. Onlara göre otel çalışanları için en önemli işten ayrılma niyetini etkileyen faktörler: çalışma koşullarının zorluğu, uzun çalışma saatlerinin varlığı ve düşük ücret şeklinde ifade edilmiştir. Aslında bu temel faktörlerin de motivasyonu etkileyen faktörlerden olduğu noktasında yönetici görüşlerinde eksiklikler bulunmaktadır. Bu noktadan hareketle özellikle insan kaynakları yöneticilerinin çalışan motivasyonu üzerinde daha fazla bilgiye sahip olmaları gerektiği ve bunun için eğitim almaları gerektiği söylenebilecektir. 


\title{
EXTENDED ABSTRACT
}

\section{Effect of Motivation on Intention to Leave: A Study on Five-Star Hotels}

\author{
Seray Toksöz
}

Esenyurt University

The aim of this research is to determine the motivation levels of those working in five-star hotels in Turkey and to examine its possible effects on the intention to leave. In order to achieve the aim of this research, a realistic approach was adopted and a descriptive approach was chosen from the research methodologies. In order to carry out a descriptive study, a structured questionnaire was applied in this study and both primary and secondary data were used.

In terms of data collection, the research consists of three stages. In the first stage, secondary data research was conducted. The purpose of secondary data research is to review the theoretical framework and to form the infrastructure of this research. In other words, secondary data were collected in order to create the conceptual framework in the study. In secondary data collection, books and articles on employee motivation were scanned. In the next stage, primary data were collected through a semi-structured questionnaire. The purpose of the survey is to examine the motivation levels of the employees working in five-star hotels in Turkey and to examine their intention to leave the job and to reveal the relationship between them, if any. The questionnaire prepared for this purpose consists of three parts. The first part of the questionnaire included a demographic questionnaire. A total of 6 questions were asked in this form. These questions are related to the gender, age, marital status, education level, employment status and working time of the participants. In order to determine the motivation levels of the participants, Gagne et al. (2010) "Multidimensional Job Motivation Scale" was used. In this part of the questionnaire, 18 questions were asked and answers were received in a 7-point Likert system. The scale consists of 6 sub-dimensions in total: "nonmotivation, external regulation-social, external regulation-material, introjected regulation, personal regulation and intrinsic motivation". In the last part of the questionnaire, the "Intention to Leave Scale" developed by Rosin and 
Korabik (1991) was used to measure the intention to leave the job. This scale consists of 4 questions in total and is answered on a 5-point Likert scale. In the third and final stage of the research, semi-structured face-to-face interviews were conducted with the managers of the human resources department of the selected five-star hotels. The purpose of semi-structured face-toface interviews is to identify management perspectives on employee motivation.

The universe of the study is the employees of the existing five-star hotels in Turkey. Convenience sampling method was used for this study. In this sampling method, the selection of units from the population is based on easy availability and/or accessibility. In this sense, the research was carried out in 5 -star hotels in Istanbul. 5 of these hotels were selected and the research was carried out specifically for these hotels. The total number of employees in these hotels was determined as 780. For this population, the result was 359 when the sample was calculated with 99 percent reliability and 5 percent margin of error. In this sense, a total of 400 questionnaires were equally distributed to the employees of the selected hotels. A collection period of 1 month was determined and the collected questionnaires at the end of this period were included in the analysis. Although 400 questionnaires were distributed, a total of 318 questionnaires were collected back as fully filled. In this sense, a total of 318 questionnaires were included in the analysis in this study. For face-to-face interviews, a human resources manager from each selected hotel was targeted and a total of 5 face-to-face interviews were conducted.

The survey results were analyzed using SPSS. Accordingly, descriptive analyzes were made first and then relationship analyzes were made to determine the relationships that may exist between motivation and intention to leave. Face-to-face interviews were analyzed using the storytelling technique.

As a result of the data obtained, the results of the research showed that total motivation has a statistically significant and positive effect on the intention to leave. Of the motivation scale sub-dimensions, "not being motivated" sub-dimension, "intrinsic motivation" sub-dimension, "external regulationsocial" sub-dimension, "personal regulation" sub-dimension, "external regulation-material" sub-dimension and "introjected regulation" sub-dimension also has a positive and statistically significant effect on intention to leave. In this sense, it can be said that motivation completely affects the intention to leave the job in terms of hotel employees. However, according to the results 
of the face-to-face interviews conducted within the scope of this research, the lack of motivation that may exist in the employees for the managers is not an effective factor on the intention to leave. According to them, the most important factors affecting the turnover intention for hotel employees were expressed as: the difficulty of working conditions, the existence of long working hours and low wages. In fact, there are deficiencies in the views of the managers at the point that these basic factors are also among the factors affecting motivation. From this point of view, it can be said that especially human resources managers should have more information on employee motivation and they should receive training for this.

\section{Kaynakça / References}

Adams, J.S. (1963). Toward an understanding of mequity. Journal of Abnormal and Social Psychology, 67(5), 422-436.

Argyris, C. (1999). On organisational learning. Massachusetts: Blackwell Publishers.

Arnold, J., Cooper, C. ve Robertson, I. (1998). Work Psychology: Understanding Human Behaviour in the Workplace. Harlow: Financial Times.

Bartol, K.M. ve Martin, D.C. (1998). Management. London: McGraw Hill.

Beardwell, I., Holden, L. ve Claydon, T. (2007). A Contemporary approach human resource management. 5th Ed. Essex: Pearson Education Ltd.

Brigantti, G.J.R. (2004). Evaluation of job satisfaction of public schools physical educators in Puerto Rico. United States Sports Academy.

Creech, R. (1995). Employee motivation. Management Quarterly, 36, 33-40.

Csikszentmihalyi, M. (2003). Good business: Leadership, flow and the making of meaning. United Kingdom: Hodder and Stoughton.

Fisher, C.D. ve Locke, E.A. (1992). The new look in job satisfaction research and theory. In Smith, P.C., Cranny, C.J. and Stone, E.F. (Eds.). Job Satisfaction: How People Feel about their Jobs and How it Affects their Performance. New York: Lexington Books, pp. 165-194.

Frazer-Robinson, J. (1999). Mastering motivation. United Kingdom: Grant Publishing.

Gagne, M., Forest, J., Gilbert, M.H., Aube, C., Morin, E. ve Malorni A. (2010). The motivation at work scale: validation evidence in two languages. Educational and Psychological Measurement, 70(4), 628-646.

Ghiselli, F.R., La Lopa, M.J. ve Bai, B. (2001). Job satisfaction, life satisfaction and turnover intent. cornell hotel and restaurant Administration Quarterly, 42(2), 28-37. 
Greenberg, J. ve Baron, R.A. (1997). Behaviour in organizations: Understanding and managing the human side of work. New Jersey: Prentice-Hall.

Hall, D.T. ve Nougaim, K.E. (1968). An examination of maslow's need of hierarchy in an organisational setting. Organisational Behaviour and Human Performances, 3, 12-35.

Herzberg, F. (1968). Once more time: How do you motivate employees. Harvard Business Review, January - February.

Herzberg, F. Mausner, B. ve Snyderman, B.B. (1967). Motivation at work. 2nd Ed. New York: John Wiley and Sons, Inc.

Hobfoll, S.E. (2001). The influence of culture, community, and the nested-self in the stress rocess: Advancing conservation of resources theory. Applied Psychology: An International Review, 50(3), 337-421.

Huczynski, A. ve Buchanan, D. (2001). Organisational behaviour: An introductory text. 4th Ed. Harlow: Prentice Hall.

Koçel, T. (2015). Issletme yöneticiliği. 17th Ed. İstanbul: Beta Yayınları.

Kök, S.B. (2006). İş tatmini ve örgütsel bağlllı̆̆ın incelenmesine yönelik bir araştırma. Atatürk Üniversitesi, İktisadi ve İdari Bilimler Fakültesi Dergisi, 20(1), 291-317.

Kotler, J. (1999). What leaders really do. Boston: Harvard Business Review Book.

Kouzes, J. ve Posner, B. (1995). The leadership challenge. San Francisco: Jossey-Bass Inc.

Küçüközkan, Y. (2015). Liderlik ve motivasyon teorileri: Kuramsal bir çerçeve. Uluslararası Akademik Yönetim Bilimleri Dergisi, 1(2), 86-115.

Martinez, J. (2001). Assessing quality, outcome and performance management. Geneva: World Health Organization.

Maslow, A. (1954). Motivation and personality. Harper and Row Publishers.

Mullins, L. (2005). Management and organisational behaviour. 7th Ed. Essex: Pearson Education.

Örücü, E. ve Esenkal, F. (2005). Konaklama işletmelerinde iş gören tatminini etkileyen faktörler (Bandırma ve Erdek Örneği). Balıkesir Üniversitesi Sosyal Bilimler Enstitüsü Dergisi, 8(14), 141-166.

Robbins, S.P., Odendaal, A. ve Roodt, G. (2003). Organisational behaviour. 9th Ed. Cape Town: Prentice-Hall International.

Rosin, H.M. ve Korabik, K. (1991). Workplace variables, affective responses, and intention to leave among women managers. Journal of Occupational Psychology, 64(4), 317-330.

Tyson, S. ve York, A. (2002) Human resource management. 3rd Ed. Kent: Martins the Printers.

Vroom, V. H. (1964). Work and motivation. New York: John Wiley and Sons. 
Yoon, M.H. ve Suh, J. (2003). Organizational citizenship behaviors and service quality as external effectiveness of contact employees. Journal of Business Research, 56(8), 597-611.

Yüksel, İ. (2002). Hemşirelerin iş tatmin düzeylerini ayırt edici iş tatmin öğelerinin diskriminant analiziyle belirlenmesi. Kocaeli Üniversitesi Sosyal Bilimler Enstitüsü Dergisi, 3(1), 67-78.

Yürür, S. ve Keser, A. (2011). İşe bağlı gerginlik ile iş tatmini ilişkisinde duygusal tükenmenin arac rolü. Ankara Üniversitesi SBF Dergisi, 65(4), 165-193.

\section{Kaynakça Bilgisi / Citation Information}

Toksöz, S. (2021). Motivasyonun işten ayrılma niyeti üzerine etkisi: beş yıldızlı oteller üzerinde bir uygulama. OPUS-Uluslararası Toplum Araştırmaları Dergisi, 18(41), 3280-3301. DOI: 10.26466/ opus.898036. 